\title{
Voltammetric Behaviour of Drug Molecules as a Predictor of Metabolic Liabilities
}

\author{
Hikari Fuchigami ${ }^{1}{ }^{(}$, Mandeep K. Bal $^{2}$, Dale A. C. Brownson ${ }^{2}\left(\mathbb{D}\right.$, Craig E. Banks ${ }^{2}(\mathbb{D}$ \\ and Alan M. Jones ${ }^{3, * \mathbb{D}}$ \\ 1 School of Biosciences, University of Birmingham, Edgbaston B15 2TT, UK; HXF916@student.bham.ac.uk \\ 2 Faculty of Science and Engineering, Manchester Metropolitan University, Chester Street, \\ Manchester M1 5GD, UK; m.kaur@mmu.ac.uk (M.K.B.); D.Brownson@mmu.ac.uk (D.A.C.B.); \\ C.Banks@mmu.ac.uk (C.E.B.) \\ 3 School of Pharmacy, University of Birmingham, Edgbaston B15 2TT, UK \\ * Correspondence: a.m.jones.2@bham.ac.uk; Tel.: +44-01214-147-288
}

Received: 15 September 2020; Accepted: 3 October 2020; Published: 13 October 2020

check for updates

\begin{abstract}
Electron transfer plays a vital role in drug metabolism and underlying toxicity mechanisms. Currently, pharmaceutical research relies on pharmacokinetics (PK) and absorption, distribution, metabolism, elimination and toxicity (ADMET) measurements to understand and predict drug reactions in the body. Metabolic stability (and toxicity) prediction in the early phases of the drug discovery and development process is key in identifying a suitable lead compound for optimisation. Voltammetric methods have the potential to overcome the significant barrier of new drug failure rates, by giving insight into phase I metabolism events which can have a direct bearing on the stability and toxicity of the parent drug being dosed. Herein, we report for the first time a data-mining investigation into the voltammetric behaviour of reported drug molecules and their correlation with metabolic stability (indirectly measured via $t_{1 / 2}$ ), as a potential predictor of drug stability/toxicity in vivo. We observed an inverse relationship between oxidation potential and drug stability. Furthermore, we selected and prepared short- ( $<10 \mathrm{~min})$ and longer-circulation $(>2 \mathrm{~h}) \mathrm{drug}$ molecules to prospectively survey the relationship between oxidation potential and stability.
\end{abstract}

Keywords: voltammetry; metabolism; stability; toxicity; drug; electron transfer; half-life; propanidid; drug discovery

\section{Introduction}

Electron transfer is an innate property of biological processes in the body [1]. When xenobiotics are introduced to the body (e.g., drug molecules) they encounter a variety of potential redox modulations, including cytochrome p450 (CYP450) enzymes. This metabolic redox biotransformation of the drug facilitates the elimination of the xenobiotic as a more polar drug metabolite [2]. However, redox biotransformations are not always a detoxification process [3]. Oxidation is the primary mechanism of reactive electrophilic metabolite formation, and these in turn react with nucleophiles such as DNA or proteins by forming irreversible covalent bonds, which leads to adverse reactions [4]. These redox events can be measured by voltammetric techniques [5].

One barrier to bringing a new drug to market is the high failure rate. Current methods rely on pharmacokinetics and ADMET measurements [2] in order to identify lead compounds and their optimisation [6]. Electrochemistry (EC) is a relatively new and innovative approach to supporting drug discovery [3]. EC is an alternative method to study drug metabolism and toxicities in early phases by mimicking phase I metabolism [7-10]. Crucially, most marketed drugs (including pro-drugs) show electroactivity at solid electrodes $[4,11]$. 
Our interest in connecting the voltammetric behaviour of drug molecules to their biological properties is derived from our research into the electrochemistry of small molecules [12-14] and adverse drug reactions $[15,16]$. Recent disparate research has found connections between the redox behaviour of a drug and its biological potency [17-19] and the oxidation potential and toxicity of MDMA (Ecstasy) derivatives [20,21] and thiobenzamides [22], and voltammetric studies for assessing electrogenerated drug metabolisms [23] as well as a study of xeniobiotics in the environment [24].

Inspired by these connections between the biological properties and voltammetric behaviours of selected drug molecules, we report on our investigations into the emerging connectivity between oxidation potential and drug stability, via:

1. Data mining the existing literature for the half-life and oxidation potential values of known drugs;

2. Correlating standardised redox measurements with stability measures;

3. Analysing examples of short and longer circulating drug molecules to determine their voltammetric parameters.

We hypothesised that oxidation potential correlates with drug stability, as it is assumed lower oxidation potential (OP) indicates an easier biotransformation. Thus, a drug compound with a shorter half-life $\left(\mathrm{t}_{1 / 2}\right)$ may have a lower OP.

\section{Materials and Methods}

\subsection{Data Mining}

A systematic approach to locating relevant literature sources was adopted using the search engines and databases Sci-Finder, Reaxys and PubChem. Key operator descriptors and Boolean logic were used \{oxidation potential; voltammetry; drug; metabolism; half-life; redox\} to generate the list of drugs (up until July 2020) that had both a reported redox value and a surrogate biological measure of metabolic stability, although not necessarily from the same source.

Reference electrode data was standardised (where provided) using http://www.consultrsr.net/ resources/ref/refpotls3.htm

\subsection{General Points}

All commercial reagents and solvents were used as received without further purification. All novel voltammetry experiments were performed using an Autolab potentiostat (PGSTAT 100N, The Netherlands). The progress of reactions was monitored by thin layer chromatography (TLC) using Merck silica gel 60 F254 plates, which were visualized with UV light. Reactions were purified using flash column chromatography (ethyl acetate: petroleum ether) using high-purity grade, pore size $60 \AA$, 200-400 mesh particle size silica gel (Sigma-Aldrich, Gillingham, UK).

${ }^{1} \mathrm{H}$ and ${ }^{13} \mathrm{C}$-NMR spectra were recorded on a JEOL ECS $400 \mathrm{MHz}$ NMR spectrometer. ${ }^{1} \mathrm{H}$ and ${ }^{13} \mathrm{C}$ NMR chemical shifts $(\delta)$ are reported in parts per million relative to tetramethylsilane (TMS), with the solvent resonance employed as the internal standard $\left(\mathrm{CDCl}_{3}\right.$ at $7.26 \mathrm{ppm}, \mathrm{CDCl}_{3}$ at $\left.77.2 \mathrm{ppm}\right)$. Data are reported as follows: chemical shift, multiplicity ( $\mathrm{s}=$ singlet, $\mathrm{br} \mathrm{s}=$ broad singlet, $\mathrm{d}=$ doublet, $\mathrm{t}=$ triplet, $\mathrm{q}=$ quartet, $\mathrm{qt}=$ quintet, sext = sextet, $\mathrm{m}=$ multiplet and combinations thereof), coupling constants $(\mathrm{Hz})$ and integration. Low- and high-resolution mass spectrometry analysis was obtained using an Agilent 6450 LC-MS/MS system in electrospray ionisation positive mode $\left(\mathrm{ESI}^{+}\right)$.

\subsection{General Procedures for Linear Sweep Voltammetry (LSV)}

LSV experiments were performed using a glassy carbon electrode (GCE, geometric area $=0.071$ $\mathrm{cm}^{2}$ ) as the working electrode (WE), a platinum wire was used as a counter electrode (CE) and $\mathrm{Ag} / \mathrm{AgCl}$ wire was used as a reference electrode (RE). Tetrabutylammonium perchlorate (TBAP) was used as the supporting electrolyte in a $\mathrm{MeCN}: \mathrm{MeOH}(10: 1)$ solvent mixture. Prior to each experiment and in-between scan rate studies, the GCE was polished manually, first with $1.0 \mu \mathrm{m}$ diamond spray (Kemet, 
Maidstone, UK) on a smooth velvet polishing pad (BASi, West Lafayette, IN, USA). The GCE was rinsed with distilled water and a second polishing was performed using $0.25 \mu \mathrm{m}$ diamond spray (Kemet) on a smooth velvet polishing pad (BASi, West Lafayette, IN, USA). Finally, the GCE was rinsed with distilled water and then dried prior to the experiment. The linear regression equations were calculated by the least squares method using Microsoft Excel ${ }^{\circledR}$ software.

\subsection{Compound Characterisation}

\subsubsection{3-Methoxy-4-hydroxyphenylacetic Acid Propyl Ester (2)}

In a pressure tube equipped with magnetic stirrer, 4-hydroxy-3-methoxyphenethyl alcohol, 1, $(12.0 \mathrm{mmol})$ was dissolved in anhydrous propan-1-ol $(0.27 \mathrm{M}, 21.0 \mathrm{~mL})$. To this solution, concentrated sulfuric acid $(1.0 \mathrm{~mL})$ was added and the solution was heated at $100{ }^{\circ} \mathrm{C}$ for $5 \mathrm{~h}$. Upon completion, the solvent was removed under reduced pressure. The resulting oil was diluted with ethyl acetate $(40.0 \mathrm{~mL})$, and washed with saturated sodium bicarbonate $(20.0 \mathrm{~mL})$, distilled water $(20.0 \mathrm{~mL})$ and brine $(20.0 \mathrm{~mL})$. The organic layer was dried $\left(\mathrm{MgSO}_{4}\right)$, filtered and concentrated in vacuo to afford the title compound as a red oil ( $2.45 \mathrm{~g}, 86 \%$ ) (Figures $\mathrm{S} 1$ and S2). ${ }^{1} \mathrm{H}-\mathrm{NMR}\left(400 \mathrm{MHz}, \mathrm{CDCl}_{3}\right) \delta: \mathrm{ppm}$ 6.90-6.80 (m, 1H), $6.81(\mathrm{~d}, J=1.4 \mathrm{~Hz}, 1 \mathrm{H}), 6.80-6.70(\mathrm{~m}, 1 \mathrm{H}), 5.60(\mathrm{~s}, 1 \mathrm{H}), 4.05(\mathrm{t}, J=6.6 \mathrm{~Hz}, 2 \mathrm{H})$, $3.88(\mathrm{~s}, 3 \mathrm{H}), 3.54(\mathrm{~s}, 2 \mathrm{H}), 1.71-1.52(\mathrm{~m}, 2 \mathrm{H}), 0.91(\mathrm{t}, J=7.3 \mathrm{~Hz}, 3 \mathrm{H}) ;{ }^{13} \mathrm{C}-\mathrm{NMR}\left(101 \mathrm{MHz}, \mathrm{CDCl}_{3}\right) \delta: \mathrm{ppm}$ 172.5, 146.9, 145.0, 125.8, 122.0, 114.8, 112.2, 66.5, 55.6, 40.9, 21.9, 10.3; LC-MS (ESI) $m / z 225[\mathrm{M}+\mathrm{H}]^{+}$; Hi-Res LC-MS (ESI) $m / z$ calcd. for $\mathrm{C}_{12} \mathrm{H}_{16} \mathrm{O}_{4}[\mathrm{M}+\mathrm{H}]^{+} 225.1121$, found 225.1120 .

\subsection{2. [4-[(Diethylcarbamoyl) methoxy]-3-methoxyphenyl] Acetic Acid Propyl Ester (Propanidid)}

3-Methoxy-4-hydroxyphenylacetic acid propyl ester (2) (3.4 mmol, $0.8 \mathrm{~g}$ ) was dissolved in acetone $(0.27 \mathrm{M}, 20 \mathrm{~mL})$. Potassium carbonate $(5.1 \mathrm{mmol}, 705 \mathrm{mg})$ was added to the solution, followed by 2-chloro- $\mathrm{N}, \mathrm{N}$-diethylacetamide $(4.0 \mathrm{mmol}, 0.55 \mathrm{~mL})$. Under vigorous stirring, the suspension was warmed to reflux $\left(60^{\circ} \mathrm{C}\right)$ for $16 \mathrm{~h}$. After cooling to room temperature, the reaction mixture was filtered and the solvent removed under reduced pressure. The product was purified by silica column chromatography (ethyl acetate:hexane) to afford the title compound as a pale yellow oil $(0.64 \mathrm{~g}, 56 \%)$ (Figures S3 and S4). ${ }^{1} \mathrm{H}-\mathrm{NMR}\left(400 \mathrm{MHz}, \mathrm{CDCl}_{3}\right) \delta$ : ppm $6.88(\mathrm{~d}, J=8.2 \mathrm{~Hz}, 1 \mathrm{H}), 6.82(\mathrm{~d}, J=1.4 \mathrm{~Hz}$ $1 \mathrm{H}), 6.77(\mathrm{~d}, J=8.2 \mathrm{~Hz}, 1 \mathrm{H}), 4.7(\mathrm{~s}, 2 \mathrm{H}) 4.04-3.99(\mathrm{~m}, 2 \mathrm{H}), 3.84(\mathrm{~s}, 3 \mathrm{H}), 3.52(\mathrm{~s}, 2 \mathrm{H}), 3.32-3.42(\mathrm{~m}, 4 \mathrm{H})$, 1.57-1.64 (m, 2H), 1.18-1.14 (m, 3H), 1.12-1.08 (m, 3H), 0.87-0.91 (t, J = 7.3 Hz, 3H); ${ }^{13} \mathrm{C}-\mathrm{NMR}(101 \mathrm{MHz}$, $\mathrm{CDCl}_{3}$ ) $\delta:$ ppm 170.7, 166.0, 148.4, 145.7, 127.0, 120.4, 113.2, 112.1, 67.4, 65.3, 54.7, 40.5, 39.8, 39.2, 21.0, 13.2, 11.8, 9.4; LC-MS (ESI) $\mathrm{m} / z 338[\mathrm{M}+\mathrm{H}]^{+}$; Hi-Res LC-MS (ESI) $\mathrm{m} / z$ calcd. for $\mathrm{C}_{18} \mathrm{H}_{27} \mathrm{NO}_{5}[\mathrm{M}+\mathrm{H}]^{+}$ 338.1962 , found 338.1967 .

\subsubsection{Entacapone}

Entacapone (purchased from Sigma-Aldrich, Figure S5). ${ }^{1} \mathrm{H}-\mathrm{NMR}\left(400 \mathrm{MHz}, \mathrm{CDCl}_{3}\right) \delta: \mathrm{ppm} 10.87$ $(\mathrm{s}, 1 \mathrm{H}), 8.06-8.05(\mathrm{~d}, J=2.0 \mathrm{~Hz}, 1 \mathrm{H}), 7.83-7.82(\mathrm{~d}, J=2.0 \mathrm{~Hz}, 1 \mathrm{H}), 7.51(\mathrm{~s}, 1 \mathrm{H}), 7.19(\mathrm{~s}, 1 \mathrm{H}), 6.10(\mathrm{~s}, 1 \mathrm{H})$, $3.44(\mathrm{~s}, 2 \mathrm{H}), 1.52(\mathrm{~s}, 2 \mathrm{H}), 1.25-1.17(\mathrm{~m}, 3 \mathrm{H})$.

\subsubsection{Lidocaine}

Lidocaine (purchased from Sigma-Aldrich, Figure S6). ${ }^{1} \mathrm{H}-\mathrm{NMR}\left(400 \mathrm{MHz}, \mathrm{CDCl}_{3}\right) \delta$ : ppm 8.93 (br s, 1H) 7.10-7.09 (m, 3H) $3.22(\mathrm{~s}, 2 \mathrm{H}) 2.66-2.71(\mathrm{q}, J=7.0 \mathrm{~Hz}, 4 \mathrm{H}) 2.23(\mathrm{~s}, 6 \mathrm{H}) 1.15-1.12(\mathrm{t}, J=7.0 \mathrm{~Hz}$, $6 \mathrm{H})$.

\section{Results}

\subsection{Comparison of Drug Metabolite OP to Parent Drug OP}

The selected drugs' oxidation potentials (reported, mean, and standardised OP to Normal Hydrogen Electrode (N.H.E.) where sufficient data are available) alongside the mean half-life 
measurements are shown in Table 1. It was found that drug metabolites tended to have lower OP than the parent drug molecules, including Diclolfenac $(700 \mathrm{mV})$ vs. $4^{\prime}-\mathrm{OH}-\mathrm{DCL}(167 \mathrm{mV})$ and $5^{\prime}$-OH-DCL $(236 \mathrm{mV})$, Clozapine $(475 \mathrm{mV})$ vs. Norclozapine $(390 \mathrm{mV})$, and Flupirtine $(443 \mathrm{mV})$ vs. $\mathrm{D} 13223(347 \mathrm{mV})$.

Table 1. Oxidation potential (OP) and half-life of identified compounds.

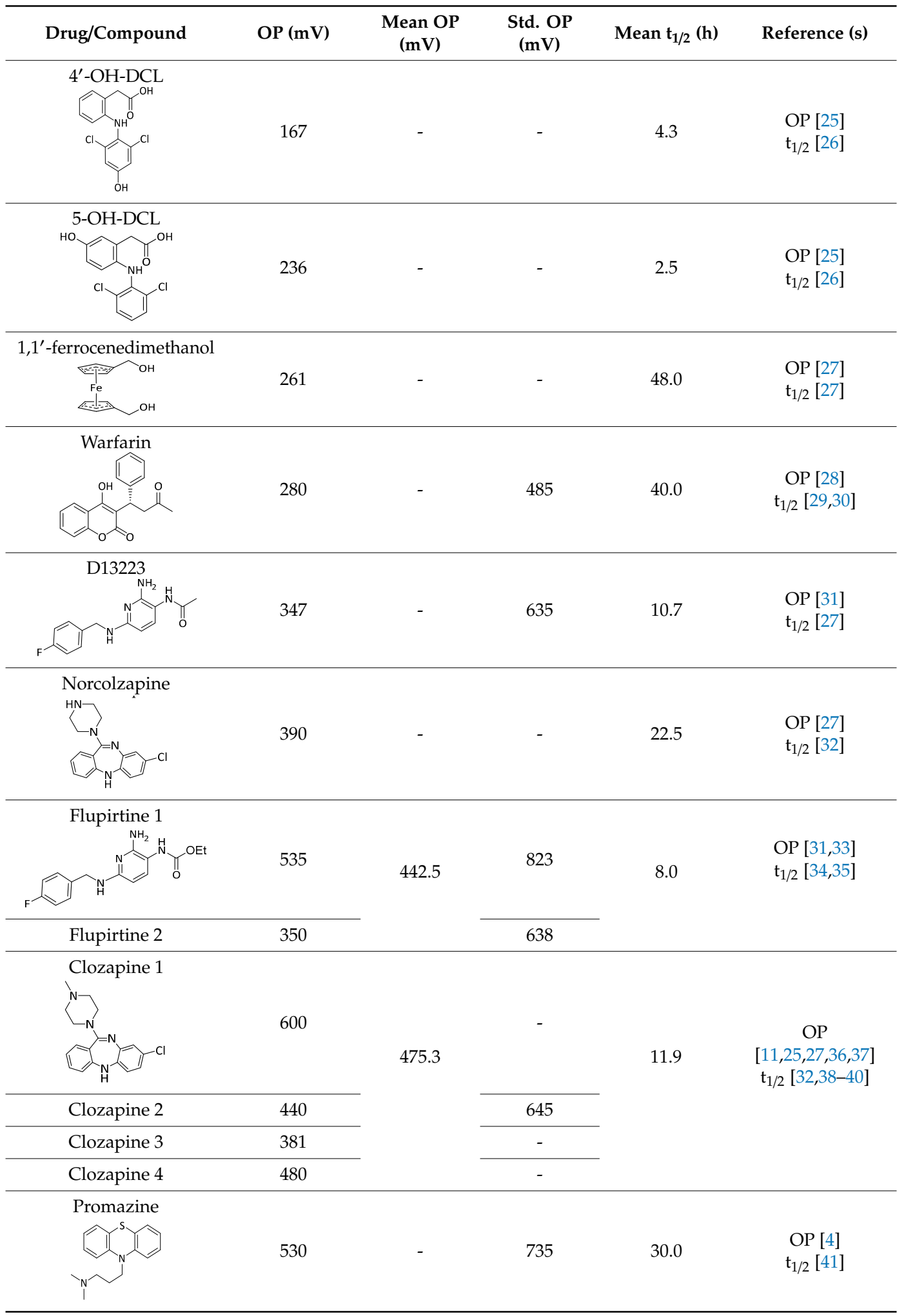


Table 1. Cont.

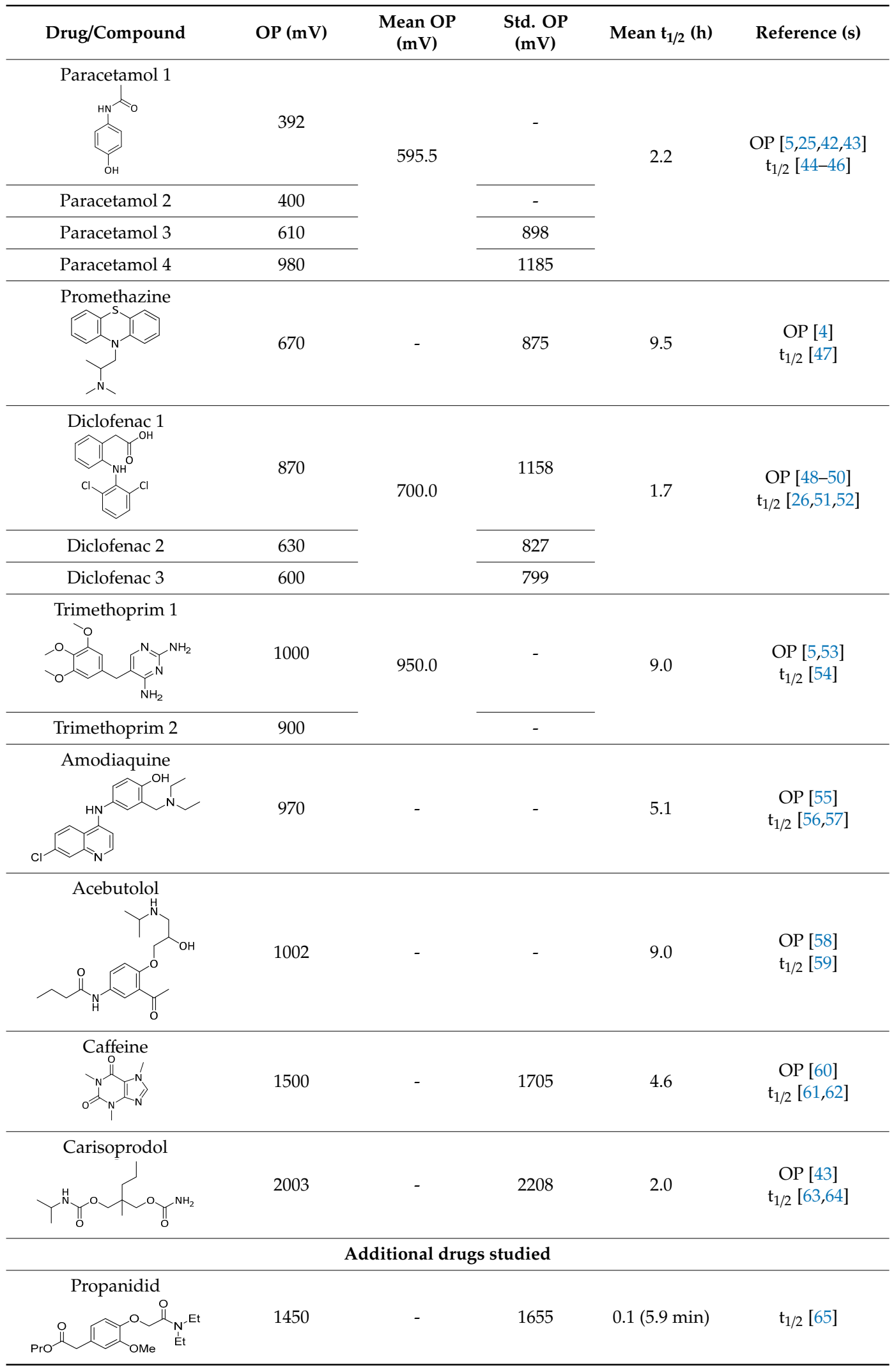


Table 1. Cont.

\begin{tabular}{lccccc}
\hline Drug/Compound & OP (mV) & $\begin{array}{c}\text { Mean OP } \\
(\mathbf{m V})\end{array}$ & $\begin{array}{c}\text { Std. OP } \\
(\mathbf{m V})\end{array}$ & Mean $\mathbf{t}_{1 / 2}(\mathbf{h})$ & Reference (s) \\
\hline & & & & \\
\hline
\end{tabular}

Compounds with sufficient data (e.g., concentration of electrolytes, reference electrode used) enabled the calculation of the standardised (std.) OP to the normal hydrogen electrode (N.H.E.).

\subsection{Relationship between Drug OP and Half-Life}

The relationships between all drugs/metabolites' OPs with half-life are shown in Figure 1a. The relationships of only those molecules the OP of which could be standardised to N.H.E. against mean half-life are shown in Figure 1b. In all cases, an inverse relationship between OP and half-life was observed.

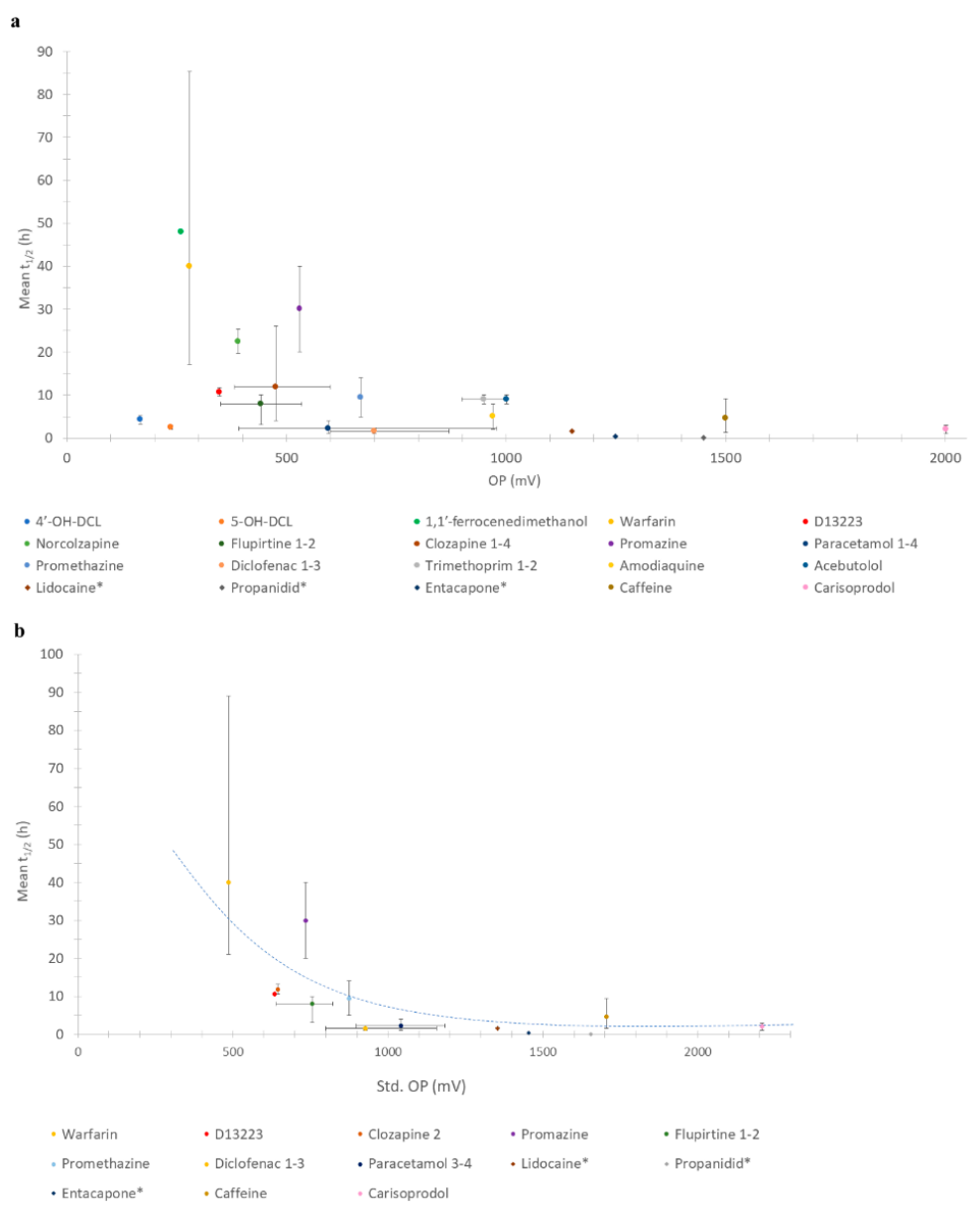

Figure 1. (a) Relationship between OP and half-life of all compounds; (b) Relationship between standardised OP (N.H.E.) and half-life. Key: ${ }^{*}=$ additional drugs studied and number after the drug indicates which entries from Table 1 were standardized. 


\subsection{Synthesis of Propanidid}

The synthetic pathway to the short acting anaesthetic propanidid is shown in Scheme 1. Propanidid was synthesised using an adapted method (in two steps) [68]. Fischer esterification of the carboxylic acid (1) with propan-1-ol in a pressure tube afforded the desired ester (2) in an excellent isolated yield $(86 \%)$. The reaction of the ester (2) with carbamoyl chloride afforded propanidid in a good isolated yield $(56 \%)$ after chromatography.
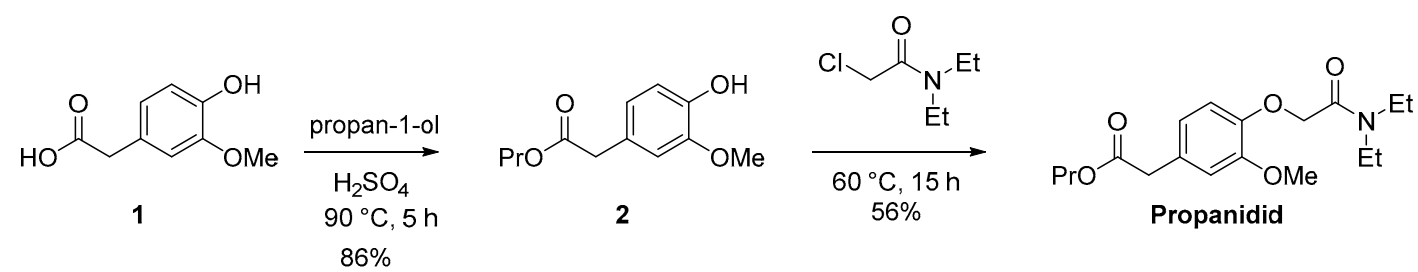

Scheme 1. Adapted synthesis of propanidid to enable the voltammetric study.

\subsection{Voltammetric Study of Propanidid, Entacapone and Lidocaine.}

The additional short- and long-acting drugs propanidid, entacapone and lidocaine's LSV measurements are shown in Figure $2 \mathrm{a}-\mathrm{c}$. Two clear $\mathrm{E}_{\mathrm{p}}{ }^{\text {ox }}$ are observed at $+1.15 \mathrm{~V}$ and $+1.97 \mathrm{~V}$ for lidocaine $\left(v=25 \mathrm{mV} \mathrm{s}^{-1}\right)$, indicating that an ECE (electrical-chemical-electrical) reaction occurred.

(a)

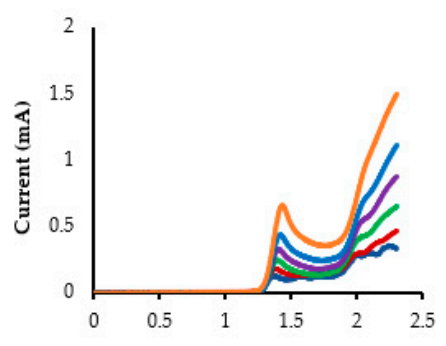

(b)

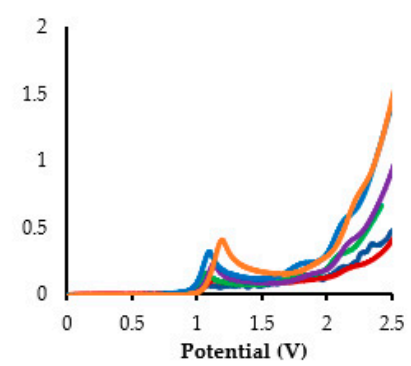

(c)

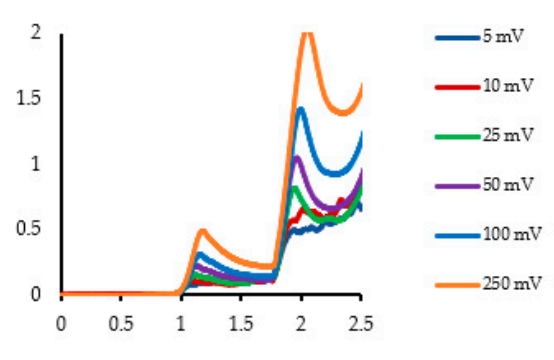

Figure 2. The LSV of the compounds using glassy carbon electrode (GCE) as the working electrode (WE), platinum as the counter electrode (CE) and $\mathrm{Ag} / \mathrm{AgCl}$ as the reference electrode(RE). TBAP (0.5 M), MeCN: MeOH (10:1). (a) Propanidid, (b) entacapone, and (c) lidocaine.

The LSV of lidocaine indicates that an electrochemical oxidation process occurs through two consecutive electron-transfer processes separated by a chemical deprotonation-first an electrochemical oxidation and deprotonation to the amidyl radical and then a further oxidation to the corresponding cation. Gieshoff [69] has observed a similar oxidation mechanism with anilides.

The LSVs of propanidid and entacapone indicate that multiple electron transfer reactions are taking place. However, apart from the first $\mathrm{E}_{\mathrm{p}}{ }^{\mathrm{ox}}$ values that are clearly visible, the other oxidation peaks occur after $2.0 \mathrm{~V}$, and are all broad and undefined.

Analysis of the LSV data in terms of log peak current (Ip) vs. $\log$ scan rate $\left(\mathrm{mV} \mathrm{s}^{-1}\right)$ for the three drugs was performed, revealing in all three cases that the gradient is close to 0.5 , indicating that the electrochemical process is operating via a diffusional process (rather than adsorption) [70-73]. It is readily observable that the peak potential shifts to more positive potentials due to the electrochemical process being irreversible. 


\section{Discussion}

\subsection{Comparing Parent Drugs to Drug Metabolites}

All retrieved drugs and metabolites data are shown in Table 1. Metabolic oxidation of diclofenac (DCL) gives the unsTable 4'-OH-DCL and 5-OH-DCL, which induce hepatoxicity and can be metabolised further. This is in accordance with the finding that the drug metabolites have lower oxidation potentials than diclofenac. 5-OH-DCL forms a GSH conjugate without NADPH, but 4'-OH-DCL relies on NADPH, which demonstrates that 5-OH-DCL is liable to auto-oxidation [25].

Clozapine undergoes first pass metabolism in the liver, mainly catalysed by CYP1A2. Clozapine increases interactions with other drugs, which induces severe adverse effects [74]. It is further metabolised to give Norclozapine and Clozapine $N$-oxide. The redox activities of Clozapine and its metabolite (Norclozapine) are similar [27].

Flupirtine metabolism gives glucuronides and mercapturic acid derivatives (via the carbamate), which are unstable and toxic. A reactive diamine radical intermediate is formed which is toxic to cells and genes [75]. Further metabolism affords D13223. D13223 is a major active metabolite of Flupirtine and is further metabolised. Compared to Flupirtine, D13223 is easily oxidised, but the reduction is more difficult [76].

It was found that drug metabolites had lower OP vlaues than the parent drug. For example, 4'-OH-DCL and 5-OH-DCL, Norclozapine and D13223 have lower OP values than their parent drugs Diclofenac, Clozapine and Flupirtine, respectively (Table 1). Furthermore, these metabolites were more toxic than the parent drug. Among the drug metabolites generated from the same parent drug, metabolites with lower OP are highly toxic compared to others (i.e., $4^{\prime}$-OH-DCL is more toxic than 5-OH-DCL).

\subsection{Drug Metabolism Pathways}

Oxidation potential (OP) can inform the ability of the compounds to generate reactive oxygen species (ROS), and therefore the oxidative stress induction [77]. More than one measurement of OP value was collected for some compounds (i.e., Paracetamol, Diclofenac, Trimethoprim, Clozapine and Flupirtine) where available. Secondly, the half-life is an important parameter to assess drug stability alongside hepatic clearance. A less stable drug is intensively metabolised, and both half-life and clearance rate are responsible for drug elimination [78]. A drug metabolite with a longer half-life is the major (most stable) product, although it is not always safe, as it implies drugs will stay in the body for an extended period before being removed. Hepatoxicity is induced because of the reactive intermediate induced by the metabolism processes. In most cases, metabolites are responsible for toxicity due to bioactivation [79].

Although the plot appeared to be random before standardising OP (Figure 1a), a stronger correlation was seen for the standardised (std.) OP (Figure 1b). As shown in Figure 1a, the peak of half-life was seen at 250-500 mV. This newly identified inverse correlation trend, whereby a lower OP has a longer half-life and vice versa, implies that a compound with a lower OP is more biologically stable, rather than reactive. However, increasing the biological stability of a drug implies metabolites (with a lower OP) may stay in the body longer.

A multitude of factors affect a drug's pharmacology, including stability and toxicity. Clearly, predicting all the drug's interactions in the body from one factor such as OP is not possible, however a rapid screen of new drug entities' (or during hit-to-lead development) OP values would give insight into the much later biological behaviour of the compound under study, and provide new knowledge to guide the intelligent design of improved drug molecules.

Due to the limited number of drugs that have both a reported OP and half-life in the literature, a statistical analysis to determine if this inversely proportional trend between OP and half-life is valid would not be relevant. 
We therefore looked at the respective drug metabolism pathways for further insight. Promazine is a metabolite of Chlorpromazine [80]. More than $80 \%$ of Promethazine is absorbed in the body, and metabolism is via first-pass (liver), glucuronidation and sulfation [81].

Acebutolol is metabolised in the liver to give hepatoxic (active) metabolites such as diacetolol, hydroxylamine and 'auto-oxidised' metabolites, which are responsible for toxicity [82]. Hydrolysis forms an arylamine, and the CYP450 oxidation of arylamine induces toxicity [82].

The organometallic 1,1'-ferrocene dimethanol is not actively metabolised.

Warfarin is metabolised by the liver in a regio- and stereo-selective manner. Oxidation gives hydroxywarfarin which accounts for up to $85 \%$ of warfarin's metabolites [83]. S- and R-warfarin are metabolised by different CYP450 isoforms, including CYP2C19 and CYP2C8 (with CYP2C19), respectively [83]. S-warfarin has a shorter half-life (mean $32 \mathrm{~h}$ ) than $R$-warfarin (mean $58 \mathrm{~h}$ ) [30].

The metabolism of Paracetamol is responsible for both its therapeutic effects and toxicity (hepatoxicity) [84]. Reactive metabolites such as the quinone are rapidly formed. Biotransformation is mainly a detoxification processes, but $N$-acetyl- $p$-benzoquinone imine (NAPQI) is responsible for hepatocyte cell death due to GSH' depletion' [85].

Only $10-20 \%$ of Trimethoprim is metabolised in the liver [86]. Children have a rapid clearance rate, three times greater than adults [87].

Amodiaquine is metabolised in the liver and neutrophils to give a metabolite (menaquinone) [88]. Accumulating metabolites increases free haem level-induced toxicity [89].

Caffeine is metabolised in the liver to give Theobromine, Paraxanthine (major) and Theophylline [90]. The cardiovascular, respiratory, renal and nervous systems are affected by caffeine intake [91].

The reaction mechanisms for Carisoprodol have not been entirely elucidated [49]. CYP2C19 is responsible for hepatic biotransformation [92].

It can be seen that the available drugs in the literature that have both oxidation potential and stability measurements (half-life) have a wide range of different metabolic pathways, thus permitting confidence in the inverse relationship between measured OP and drug half-life.

\subsection{New Drug OP Measurements and Stability Inference}

Next, we applied the knowledge gained from the data-mining experiment to previously unreported bioactive molecules to expand the data set and test the finding of an inverse relationship between OP and half-life. An under-represented drug class in the original data set is the short half-life drugs.

Propanidid was selected as a short-acting phenylacetate general anaesthetic, which has been withdrawn from the market due to its side effect of causing anaphylactic reactions. The primary metabolite for Propanidid is (4-(2-[diethylamino]-2-oxoethoxy)-3-methoxy-benzeneacetic acid (DOMA) [93]. To the best of our knowledge, no studies in the literature have reported any electrochemical data for propanidid.

Entacapone is used in the treatment of Parkinson's disease in combination with other drugs. The primary metabolite is the glucuronide formed in the liver, and the remaining $5 \%$ is converted to the Z-isomer [94]. Several electrochemical methods have been reported in the literature for the detection of the metabolites [95-97].

Lidocaine is a local anaesthetic and is one of the most studied drugs for both the detection and isolation of a drug metabolite using electrochemical methods [98-102]. The major metabolite of lidocaine is the $N$-deethylated form.

We found that OP has an inverse relationship with the drug's stability in the body (half-life), with $1450 \mathrm{mV}, 1250 \mathrm{mV}$ and $1150 \mathrm{mV}$ correlating to $5.9 \mathrm{~min}$ [65], $24 \mathrm{~min}$ [66] and 87-108 $\mathrm{min}$ [67], for propanidid, entacapone and lidocaine, respectively. 


\subsection{Study limitations}

The limitations of the study include the following: the number of available drug molecules that have robust voltammetry information combined with half-life measurements; a lack of standardisation in the literature of electrodes (including working electrode surface area), electrolytes, solvents (including concentration), and the $\mathrm{pH}$ of the cell, which could lead to subtle differences in the measured oxidation potential via voltammetry (however, where reported, the reference electrode measurement could be standardised to an N.H.E.); the half-life of drugs in the body depends on a number of patient characteristics (age, sex, diet, underlying health conditions), thus a range of half-life measurements are to be expected.

\section{Conclusions}

Using a combination of data mining of available oxidation potential (OP) and biological stability measurements from the literature, a diverse range of drugs (and metabolites) were identified. Standardising the OP to N.H.E. and the comparison of inter-species stability measurements identified an unanticipated inverse relationship between lower OP and higher stability in vivo for the first time.

This result in part supports our original hypothesis that oxidation potential correlates with drug stability, however it conflicts with our original assumption that lower oxidation potential compounds would be more readily cleared.

A prospective survey of short-acting drug molecules, including their synthesis and characterisation, and a detailed voltammetric study indicated an emerging inverse trend between standardised OP and circulating half-life. These findings demonstrate that OP measurements hold promise as a new tool for rapidly predicting the pharmacokinetic (PK) properties of a new chemical entity for drug discovery campaigns.

Supplementary Materials: The following are available online at http://www.mdpi.com/2218-0532/88/4/46/s1, Figure S1: ${ }^{1} \mathrm{H}$ NMR spectrum of $2\left(400 \mathrm{MHz}, \mathrm{CDCl}_{3}\right)$; Figure S2. ${ }^{13} \mathrm{C}$ NMR spectrum of $2\left(101 \mathrm{MHz}, \mathrm{CDCl}_{3}\right)$; Figure S3: ${ }^{1} \mathrm{H}$ NMR spectrum of Propanidid $400 \mathrm{MHz}, \mathrm{CDCl}_{3}$ ); Figure S4: ${ }^{13} \mathrm{C} \mathrm{NMR} \mathrm{spectrum} \mathrm{of} \mathrm{Propanidid}$ $\left(101 \mathrm{MHz}, \mathrm{CDCl}_{3}\right)$; Figure S5: ${ }^{1} \mathrm{H} \mathrm{NMR}$ spectrum of Entacapone (400 MHz, $\left.\mathrm{CDCl}_{3}\right)$; Figure S6: ${ }^{1} \mathrm{H}$ NMR spectrum of Lidocaine $\left(400 \mathrm{MHz}, \mathrm{CDCl}_{3}\right)$.

Author Contributions: Conceptualization, H.F. and A.M.J.; Methodology, H.F. and M.K.B.; Validation, H.F., A.M.J., M.K.B., D.A.C.B. and C.E.B.; Formal Analysis, H.F. and A.M.J.; Investigation, H.F. and M.K.B.; Data Curation, H.F. and M.K.B.; Writing-Original Draft Preparation, H.F., A.M.J. and M.K.B.; Writing-Review and Editing, H.F., A.M.J., D.A.C.B., and C.E.B.; Visualization, H.F. and M.K.B.; Supervision, A.M.J., D.A.C.B. and C.E.B.; Project Administration, A.M.J. and C.E.B. All authors have read and agreed to the published version of the manuscript.

Funding: This research received no external funding.

Acknowledgments: The authors thank the analytical staff at MMU (UK) for NMR and mass-spectrometry analyses.

Conflicts of Interest: The authors declare no conflict of interest.

\section{References}

1. Raimondi, V.; Ciccarese, F.; Ciminale, V. Oncogenic pathways and the electron transport chain: A dangerous liaison. Br. J. Cancer 2020, 122, 168-181. [CrossRef]

2. Issa, N.T.; Wathieu, H.; Ojo, A.; Byers, S.W.; Dakshanamurthy, S. Drug Metabolism in Preclinical Drug Development: A Survey of the Discovery Process, Toxicology, and Computational Tools. Curr. Drug Metab. 2017, 18, 556-565. [CrossRef]

3. Jurva, U.; Weidolf, L. Electrochemical generation of drug metabolites with applications in drug discovery and development. TrAC Trends Anal. Chem. 2015, 70, 92-99. [CrossRef]

4. Blankert, B.; Kauffmann, J.K. Electroanalytical Methods as Tools for Predictive Drug Metabolism Studies. Rev. Pharm. Biomed. Anal. 2010, 76-83. [CrossRef]

5. Madsen, K.G.; Olsen, J.; Skonberg, C.; Hansen, S.H.; Jurva, U. Development and evaluation of an electrochemical method for studying reactive phase-I metabolites: Correlation to in vitro drug metabolism. Chem. Res. Toxicol. 2007, 20, 821-831. [CrossRef] 
6. Li, Y.; Meng, Q.; Yang, M.; Liu, D.; Hou, X.; Tang, L.; Wang, X.; Lyu, Y.; Chen, X.; Liu, K.; et al. Current trends in drug metabolism and pharmacokinetics. Acta Pharm. Sin. B 2019, 9, 1113-1144. [CrossRef] [PubMed]

7. Gul, T.; Bischoff, R.; Permentier, H.P. Electrosynthesis methods and approaches for the preparative production of metabolites from parent drugs. TrAC Trends Anal. Chem. 2015, 70, 58-66. [CrossRef]

8. Rahman, M.H.; Bal, M.K.; Jones, A.M. Metabolism Inspired Electrosynthesis. ChemElectroChem 2019, 6, 4093-4104. [CrossRef]

9. Bal, M.K.; Banks, C.E.; Jones, A.M. Metabolism mimicry: An electrosynthetic method for the selective deethylation of tertiary benzamides. ChemElectroChem 2019, 6, 4284-4291. [CrossRef]

10. Wetzel, A.; Jones, A.M. Electrically driven $N\left(\mathrm{sp}^{2}\right)-C\left(\mathrm{sp}^{2 / 3}\right)$ bond cleavage of sulfonamides. ACS Sustain. Chem. Eng. 2020, 8, 3487-3493. [CrossRef]

11. Tammari, E.; Nezhadali, A.; Lotfi, S.; Mohammadizadeh, M.R. Electrosynthesis of Clozapine Drug Derivative via an EC Electrochemical Mechanism. Anal. Bioanal. Chem. Res. 2017, 4, 319-328.

12. Alfonso-Súarez, P.; Kolliopoulos, A.V.; Smith, J.P.; Banks, C.E.; Jones, A.M. An Experimentalists Guide to Electrosynthesis: The Shono Oxidation. Tetrahedron Lett. 2015, 56, 6863-6867. [CrossRef]

13. Barone, M.R.; Jones, A.M. Selective C-H Bond Electro-oxidation of Benzylic Acetates and Alcohols to Benzaldehydes. Org. Biomol. Chem. 2017, 15, 10010-10015. [CrossRef]

14. Jones, A.M.; Banks, C.E. The Shono-type electroorganic oxidation of unfunctionalised amides. Carbon-carbon bond formation via electrogenerated $N$-acyliminium ions. Beilstein J. Org. Chem. 2014, 10, 3056-3072. [CrossRef]

15. Ferro, C.J.; Solkhon, F.; Jalal, Z.; Al-Hamid, A.M.; Jones, A.M. Relevance of physicochemical properties and functional pharmacology data to predict the clinical safety profile of direct oral anticoagulants. Pharmacol. Res. Perspect. 2020, 8, e00603. [CrossRef]

16. Jalal, Z.; Cabdi, S.; Khan, N.; Dorsch, M.; Gill, N.K.; Toner, F.; Jones, A.M. Sacubitril/Valsartan (Entresto) hospital prescribing in patients with symptomatic chronic HF with reduced ejection fraction: A UK multi-centre study. J. Prescrib. Prac. 2019, 1, 182-192. [CrossRef]

17. Baranowska, M.; Suliborska, K.; Chrzanowski, W.; Kusznierewicz, B.; Namiesnik, J.; Bartoszek, A. The relationship between standard reduction potentials of catechins and biological activities involved in redox control. Redox Biol. 2018, 17, 355-366. [CrossRef]

18. De Abreu, D.C.; Ferraz, P.A.D.L.; Goulart, M.O.F. Some Applications of Electrochemistry in Biomedical Chemistry. Emphasis on the Correlation of Electrochemical and Bioactive Properties. J. Braz. Chem. Soc. 2002, 13, 19-35. [CrossRef]

19. Verduzco-Ramirez, A.; Manzanilla-Davila, S.G.; Morales-Guillen, M.E.; Garcia-Ramos, J.C.; Toledano-Magana, Y.; Marin-Becerra, A.; Flores-Alamo, M.; Ortiz-Frade, L.A.; Olguin-Contreras, L.F.; Ruiz-Azuara, L. Essential Metal-based drugs: Correlation between Redox Potential and Biological Activity of $\mathrm{M}^{2+}$ with a $\mathrm{N}_{2} \mathrm{O}_{2}$ Ligand. J. Mex. Chem. Soc. 2017, 61, 109-119. [CrossRef]

20. Carvalho, M.; Remiao, F.; Milhazes, N.; Borges, F.; Fernandes, E.; Monteiro, M.d.C.; Goncalves, M.J.; Seabra, V.; Amado, F.; Carvalho, F.; et al. Metabolism is required for the expression of ecstasy-induced cardiotoxicity in vitro. Chem. Res. Toxicol. 2007, 17, 623-632. [CrossRef]

21. Macedo, C.; Branco, P.S.; Ferreira, L.M.; Lobo, A.M.; Capela, J.P.; Fernandes, E.; Bastos, M.d.L.; Carvalho, F. Synthesis and Cyclic Voltammetry Studies of 3,4-Methylenedioxymethamphetamine (MDMA) Human Metabolites. J. Health Sci. 2007, 53, 31-42. [CrossRef]

22. Coppola, G.M.; Anjaria, H.; Damon, R.E. Correlation of oxidation potential and toxicity in thiobenzamides. Bioorg. Med. Chem. Lett. 1996, 6, 139-142. [CrossRef]

23. Rodriguez-Cid, L.; Sentellas, S.; Saurina, J. Voltammetric and electrogeneration approaches for the assessment of the oxidative drug metabolism. Anal. Bioanal. Chem. 2018, 410, 2229-2239. [CrossRef] [PubMed]

24. Hoffman, T.; Hofmann, D.; Klumpp, E. Electrochemistry-mass spectrometry for mechanistic studies and simulation of oxidation processes in the environment. Anal. Bioanal. Chem. 2011, 399, 1859-1868. [CrossRef] [PubMed]

25. Madsen, K.G.; Skonberg, C.; Jurva, U.; Cornett, C.; Hansen, S.H.; Johansen, T.N.; Olsen, J. Bioactivation of Diclofenac in vitro and in vivo: Correlation to Electrochemical Studies. Chem. Res. Toxicol. 2008, 21, 1107-1119. [CrossRef]

26. Landsdorp, D.; Vree, T.B.; Janssen, T.J.; Guelen, P.J. Pharmacokinetics of rectal diclofenac and its hydroxy metabolites in man. Int. J. Clin. Pharmacol. Ther. Toxicol. 1990, 28, 298-302. 
27. Winkler, T.E.; Lederer, S.L.; Kim, E.; Ben-Yoav, H.; Kelly, D.L.; Payne, G.F.; Ghodssi, R. Molecular processes in an electrochemical clozapine sensor. Biointerphases 2017, 12, 02B401. [CrossRef]

28. Yang, M.; Kabulski, J.L.; Wollenberg, L.; Chen, X.; Subramanian, M.; Tracy, T.S.; Lederman, D.; Gannett, P.M.; $\mathrm{Wu}, \mathrm{N}$. Electrocatalytic Drug Metabolism by CYP2C9 Bonded to A Self-Assembled Monolayer-Modified Electrode. Drug Metab. Dispos. 2009, 37, 892-899. [CrossRef]

29. ADVANZ Pharma $(1998,2018)$. Warfarin $0.5 \mathrm{mg}$ Tablets. Available online: https://www.medicines.org.uk/ emc/product/2803/smpc (accessed on 6 October 2020).

30. Bristol-Myers Squibb Canada. PrCOUMADIN®Warfarin Sodium Tablets, Bristol-Myers Squibb Std., (Crystalline) Montreal, Canada. 2018. Available online: https://www.bms.com/assets/bms/ca/documents/ productmonograph/COUMADIN_EN_PM.pdf (accessed on 28 August 2020).

31. Methling, K.; Reszka, P.; Lalk, M.; Vrana, O.; Scheuch, E.; Siegmund, W.; Terhaag, B.; Bednarski, P.J. Investigation of the in vitro metabolism of the analgesic flupirtine. Drug Metab. Dispos. 2009, 37, 479-493. [CrossRef]

32. Renwick, A.C.; Renwick, A.G.; Flanagan, F.J.; Ferner, R.E. Monitoring of clozapine and norclozapine plasma concentration-time curves in acute overdose. J. Toxicol. Clin. Toxicol. 2000, 38, 325-328. [CrossRef]

33. Lemmerhirt, C.J.; Rombach, M.; Bodtke, A.; Bednarski, P.J.; Link, A. Oxidation Potentials of N-Modified Derivatives of the Analgesic Flupirtine Linked to Potassium KV7 Channel Opening Activity but Not Hepatocyte Toxicity. ChemMedChem 2014, 10, 368-379. [CrossRef] [PubMed]

34. Siegmund, W.; Modess, C.; Scheuch, E.; Methling, K.; Keiser, M.; Nassif, A.; Rosskopf, D.; Bednarski, P.J.; Borlak, J.; Terhaag, B. Metabolic activation and analgesic effect of flupirtine in heatlhy subjects, influence of the polymorphic NAT2, UGT1A1 and GSTP1. Br. J. Clin. Pharmacol. 2014, 79, 501-513. [CrossRef] [PubMed]

35. Patil, M.A.; Matter, B.A.; Raol, Y.H.; Bourne, D.W.A.; Kelley, R.A.; Kompella, U.B. Brain Distribution and Metabolism of Flupirtine, a Nonopioid Analgesic Drug with Antiseizure Effects, in Neonatal Rats. Pharmaceutics 2018, 10, 281. [CrossRef] [PubMed]

36. Temocin, Z.; Kim, E.; Li, J.; Panzella, L.; Alfieri, M.L.; Napolitano, A.; Kelly, D.L.; Bentley, W.E.; Payne, G.F. The Analgesic Acetaminophen and the Antipsychotic Clozapine Can Each Redox-Cycle with Melanin. ACS Chem. Neurosci. 2017, 8, 2766-2777. [CrossRef] [PubMed]

37. Yu, D.; Blankert, B.; Kauffman, J.-M. Development of amperometric horseradish peroxidase based biosensors for clozapine and for the screening of thiol compounds. Biosens. Bioelectron. 2007, 22, 2707-2711. [CrossRef] [PubMed]

38. Mylan (1989, 2014). Clozaril 100 mg Tablets. Available online: https://www.medicines.org.uk/emc/product/ 10290/smpc (accessed on 6 October 2020).

39. Novartis. 2004. Available online: https://www.accessdata.fda.gov/drugsatfda_docs/label/2005/019758s054lbl. pdf (accessed on 6 October 2020).

40. NHS. Clozapine Guidelines, NHS Foundation Trust, Version 4. 2018. Available online: https://www.southernhealth.nhs.uk/EasysiteWeb/getresource.axd?AssetID=77706\&type=full\& servicetype=Inline (accessed on 6 October 2020).

41. Rosemont Pharmaceuticals Limited $(1985,2013)$. Promazine Hydrochloride $50 \mathrm{mg} / 5 \mathrm{~mL}$ Oral Syrup. Available online: https://www.medicines.org.uk/emc/product/6698/smpc\#: \{\}:text=It\%20is\%20highly\% (accessed on 6 October 2020).

42. Berte, M.; Appia, F.T.A.; Sanogo, I.; Ouattara, L. Electrochemical Oxidation of the Paracetamol in its Commercial Formulation on Platinum, and Ruthenium Dioxide Electrodes. Int. J. Electrochem. Sci. 2016, 11, 7736-7749. [CrossRef]

43. Eisele, A.P.P.; Valezi, C.F.; Sartori, E.R. Exploiting the high oxidation potential of carisoprodol on a boron-doped diamond electrode: An improved method for its simultaneous determination with acetaminophen and caffeine. Analyst 2017, 142, 3514-3521. [CrossRef]

44. Zentiva. Paracetamol 500mg Soluble Tablets. 2018. Available online: https://www.medicines.org.uk/emc/ product/4199/smpc (accessed on 6 October 2020).

45. Prescott, L.F. Kinetics and metabolism of paracetamol and phenacetin. Br. J. Clin. Pharmacol. 1980, 10, 291S-298S. [CrossRef]

46. Medscape. Acetaminophen (OTC). Available online: https://reference.medscape.com/drug/tylenolacetaminophen-343346\#10 (accessed on 29 July 2020). 
47. Sanofi-Aventis Consumer Healthcare $(1998,2019)$. New Zealand Data Sheet, Phenergan-Promethazine Hydrochloride. Available online: https://www.medsafe.govt.nz/profs/Datasheet/p/Phenergantabelixir.pdf (accessed on 6 October 2020).

48. Ciltas, U.; Yilmaz, B.; Kaban, S.; Akcay, B.K.; Nazik, G. Square Wave Voltammetric Determination of Diclofenac in Pharmaceutical Preparations and Human Serum. Iran. J. Pharm. Res. 2015, 14, 715-722.

49. Damiri, S.; Oskoei, Y.M.; Fouladgar, M. Highly sensitive voltammetric and impedimetric sensor based on an ionic liquied/cobalt hexacyanoferrate nanoparticle modified multi-walled carbon nanotubes electrode for diclofenac analysis. J. Exper. Nanosci. 2016, 11, 1384-1401. [CrossRef]

50. Wong, A.; Marestoni, L.D.; Sotomayor, M.D.P.T. Monitoring of diclofenac with biomimetic sensor in batch and FIA systems. J. Braz. Chem. Soc. 2014, 25, 1283-1291. [CrossRef]

51. NOVARTIS. Voltaren $囚($ Diclofenac Sodium Enteric-Coated Tablets) Tablets of 75 mg Rx Only Perscribing Information. Caguas, Puerto Rico 00726 Mova Pharmaceuticals Corporation. 2009. Available online: https://www.accessdata.fda.gov/drugsatfda_docs/label/2009/019201s038lbl.pdf (accessed on 6 October 2020).

52. Pfizer Canada ULC. ARTHROTEC (Diclofenac Sodium and Misoprostol Enteric-Coated Tablets), Action and Clinical Pharmacology. 2020. Available online: https://www.pfizermedicalinformation.ca/en-ca/arthrotec/ action-and-clinical-pharmacology\# (accessed on 29 July 2020).

53. Lecours, M.A.; Eysseric, E.; Yargeau, V.; Lessard, J.; Brisard, G.M.; Segura, P.A. Electrochemistry-High Resolution Mass Spectrometry to Study Oxidation Products of Trimethoprim. Environments 2018, 5, 18. [CrossRef]

54. Kent Pharmaceuticals Ltd. Trimethoprim 100mg Tablets. 2005. Available online: https://www.medicines.org. uk/emc/product/4059/smpc (accessed on 6 October 2020).

55. O’Neill, P.M.; Harrison, A.C.; Storr, R.C.; Hawley, S.R.; Ward, S.A.; Park, B.K. The Effect of Fluorine Substitution on the Metabolism and Antimalarial Activity of Amodiaquine. J. Med. Chem. 1994, 37, 1362-1370. [CrossRef] [PubMed]

56. Winstanley, P.; Edwards, G.; Ormes, M.; Breckenridge, A. The disposition of amodiaquine in man after oral administration. Br. J. Clin. Pharmacol. 1987, 23, 1-7. [CrossRef]

57. Msellem, M.; Morris, U.; Soe, A.; Abbas, F.B.; Ali, A.-W.; Barnes, R.; Frumento, P.; Ali, A.S.; Martensson, A.; Bjorkman, A. Increase Sensitivity of Plasmodium falciparum to Artesunate/Amodiaquine Despite 14 Years as First Line Malaria Treatment, Zanzibar. Emerg. Infect. Dis. 2020, 26, 1767-1777. [CrossRef] [PubMed]

58. Bussy, U.; Ferchaud-Roucher, V.I.; Krempf, T.M.; Silvestre, V.; Boujtita, M. Electrochemical oxidation behavior of Acebutolol and identification of intermediate species by liquid chromatography and mass spectrometry. Electrochim. Acta 2012, 69, 351-357. [CrossRef]

59. SANOFI $(1974,2019)$. Sectral 100mg Capsules. Available online: https://www.medicines.org.uk/emc/product/ 3212/smpc (accessed on 6 October 2020).

60. Tadesse, Y.; Tadese, A.; Saini, R.C.; Pal, R. Cyclic Voltammetric Investigation of Caffeine at Anthraquinone Modified Carbon Paste Electrode. Int. J. Electrochem. 2013, 2013, 849327. [CrossRef]

61. Whitseit, T.L.; Manion, C.V.; Chistensen, H.D. Cardiovascular Effects of Coffee and Caffeine. Am. J. Cardiol. 1984, 53, 919-922. [CrossRef]

62. Brachtel, D.; Richter, E.E. Absolute bioavailability of caffeine from a tablet formulation. J. Hepatol. 1992, 16, 385. [CrossRef]

63. Meda Pharmaceuticals Inc. SOMA@COMPOUND (Carisoprodol and Aspirin Tablets, USP) for Oral Use New Jersey, USA. 2009. Available online: https://www.accessdata.fda.gov/drugsatfda_docs/label/2009/ 012365s035lbl.pdf (accessed on 6 October 2020).

64. Wang, G.; Huynh, K.; Barhate, R.; Rodrigues, W.; Moore, C.; Coulter, C.; Vincent, M.; Soares, J. Validation of a New Homogeneous Immunoassay for the Detection of Carisoprodol in Urine. J. Anal. Toxicol. 2011, 35, 108-112. [CrossRef]

65. Nousiainen, $\mathrm{U}$. The effects of phenobarbital, bis-p-nitrophenyl phosphate and disulfiram on the hydrolysis of propanidid in wistar rats. Gen. Pharm. 1984, 15, 397-402. [CrossRef]

66. Forsberg, M.; Lehtonen, M.; Heikkinen, M.; Savolainen, J.; Järvinen, T.; Männistö, P.T. Pharmacokinetics and Pharmacodynamics of Entacapone and Tolcapone after Acute and Repeated Administration: A Comparative Study in the Rat. J. Pharmacol. Exper. Therap. 2003, 304, 498-506. [CrossRef] [PubMed]

67. Collinsworth, K.A.; Kalman, S.M.; Harrison, D.C. The Clinical Pharmacology of Lidocaine as an Antiarrhythmic Drug. Circulation 1974, 50, 1217-1230. [CrossRef] [PubMed] 
68. Hiltmaan, R.; Wollweber, H.; Hoffmeister, F.; Wirth, W. 3-Methoxy-4-Carbadmidomethyoxy-Phenylacetic Acid Esters. U.S. Patent 3086978, 23 April 1963.

69. Gieshoff, T.; Kehl, A.; Schollmeyer, D.; Moeller, K.D.; Waldvogel, S.R. Insights into the Mechanism of Anodic N-N Bond Formation by Dehydrogenative Coupling. J. Am. Chem. Soc. 2017, 139, 12317-12324. [CrossRef]

70. Randles, J.E.B. Kinetics of rapid electrode reactions. Discuss. Faraday Soc. 1947, 1, 11. [CrossRef]

71. Randles, J.E.B. A cathode ray polarograph. Part II.-The current-voltage curves. Trans. Faraday Soc. 1948, 44, 327. [CrossRef]

72. Sevcik, A. Oscillographic polarography with periodical triangular voltage. Collect. Czechoslov. Chem. Commun. 1948, 13, 349. [CrossRef]

73. Laviron, E.; Roullier, L.; Degrand, C. A multilayer model for the study of space distributed redox modified electrodes: Part II. Theory and application of linear potential sweep voltammetry for a simple reaction. J. Electroanal. Chem. Interfacial Electrochem. 1980, 112, 11-23. [CrossRef]

74. Pardiñas, A.F.; Nalmpanti, M.; Pocklington, A.J.; Legge, S.E.; Medway, C.; King, A.; Jansesn, J.; Helthuis, M.; Zammit, S.; MacCabe, J.M.J.; et al. Pharmacogenomic Variants and Drug Interactions Identified Through the Genetic Analysis of Clozapine Metabolism. Am. J. Psychiatry 2019, 176, 477-486. [CrossRef]

75. Siegmund, W. Pharmacokinetics, Metabolism and Analgesic Effects of Flupirtine. In Clinical Trial NCT01676246; 2012. Available online: https:/clinicaltrials.gov/ct2/show/NCT01676246 (accessed on 6 October 2020).

76. Harish, S.; Bhuvana, K.; Bengalorkar, G.M.; Kumar, T.N. Flupirtine: Clinical pharmacology. J. Anaesthesiol. Clin. Pharmacol. 2012, 28, 172-177. [CrossRef]

77. Agarwal, A.; Bui, A.D. Oxidation-reduction potential as a new marker for oxidative stress: Correlation to male infertility. Investig. Clin. Urol. 2017, 58, 385-399. [CrossRef] [PubMed]

78. Baranczewski, P.; Stanczak, A.; Kautiainen, A.; Sandin, P.; Edlund, P.O. Introduction to early in vitro identification of metabolites of new chemical entities in drug discovery and development. Pharmacol. Rep. 2006, 58, 341-352.

79. Irving, R.M.; Elfarra, A.A. Role of Reactive Metabolites in the Circulation in Extrahepatic Toxicity. Expert Opin. Drug Metab. Toxicol. 2012, 8, 1157-1172. [CrossRef] [PubMed]

80. Curry, S.H. Chapter 8-Pharmacokinetics of antipsychotic drugs. Antipsychotic Drugs and Their Side-Effects; Barnes, T.R.E., Ed.; Academic Press: San Diego, CA, USA, 1993; pp. 127-144.

81. Zabirowicz, E.S.; Gan, T.J. 34-Pharmacology of Postoperative Nausea and Vomiting. In Pharmacology and Physiology for Anesthesia, 2nd ed.; Hemmings, H.C., Egan, T.D., Eds.; Elsevier: Philadelphia, PA, USA, 2019; pp. 671-692.

82. Muta, K.; Fukami, T.; Nakajima, M. A proposed mechanism for the adverse effects of acebutolol: CES2 and CYP2C19-mediated metabolism and antinuclear antibody production. Biochem. Pharmacol. 2015, 98, 659-670. [CrossRef] [PubMed]

83. Miners, J.O.; Birkett, D.J. Cytochrome P4502C9: An enzyme of major importance in human drug metabolism. Br. J. Clin. Pharmacol. 1998, 45, 525-538. [CrossRef]

84. Mahadevan, S.B.K.; McKiernan, P.J.; Davies, P.; Kelly, D.A. Paracetamol induced hepatotoxicity. Arch. Dis. 2006, 91, 598-603. [CrossRef]

85. Athersuch, T.J.; Antoine, D.J.; Boobis, A.R.; Coen, M.; Daly, A.K.; Passamai, L.; Nicholson, J.K.; Wilson, I.D. Paracetamol metabolism, hepatotoxicity, biomarkers and therapeutic interventions: A perspective. Toxicol. Res. 2018, 7, 347-357. [CrossRef]

86. Spreux-Varoquax, O.; Chapalain, J.P.; Cordonnier, P.; Advenier, C. Determination of trimethoprim, sulfphamethoxazole and its $\mathrm{N}^{4}$-acetyl metabolite in biological fluids by high-performance liquid chromatography. J. Chromat. B Biomed. Appl. 1983, 274, 187-199. [CrossRef]

87. Hoppu, K.; Arjomaa, P. Difference in Trimethoprim Pharmacokinetics between Children and Adults. Chemotherapy 1984, 30, 283-287. [CrossRef]

88. Winnie, N.G.; Lobach, A.R.M.; Zhu, X.; Chen, X.; Liu, F.; Metushi, I.G.; Sharma, A.; Li, J.; Cai, P.; Ip, J.M.; et al. Uetrecht. Animal Models of Idiosyncratic Drug Reactions. Adv. Pharmacol. 2012, 63, 81-135.

89. Ginsburg, H.; Famin, O.; Zhang, J.; Krugliak, M. Inhibition of glutathione-dependent degradation of heme by chloroquine and amodiaquine as a possible basis for their antimalarial mode of action. Biochem. Pharmacol. 1998, 56, 1305-1313. [CrossRef] 
90. Tian, D.-D.; Natesan, S.; White, J.R.M., Jr.; Paine, F. Effects of Common CYP 1A2 Genotypes and Other Key Factors on Intraindividual Variation in the Caffeine Metabolic Ratio: An Exploratory Analysis. Clin. Transl. Sci. 2019, 12, 39-46. [CrossRef] [PubMed]

91. Institute of Medicine (US) Committee on Military Nutrition Research. Caffeine for the Sustainment of Mental Task Performance: Formulations for Military Operations; National Academies Press (US): Washington, DC, USA, 2001. Available online: https://www.ncbi.nlm.nih.gov/books/NBK223802/ (accessed on 13 October 2020).

92. Gonzalez, L.A.; Gatch, M.B.; Forster, M.J.; Dillon, G.H. Abuse Potential of Soma: The GABA(A) Receptor as a Target. Mol. Cell. Pharmacol. 2009, 1, 180-186.

93. Cenani, A.; Brosnan, R.J.; Knych, H.K. In vitro and in vivo GABA $\mathrm{A}$ Receptor Interaction of the Propanidid Metabolite 4-(2-[Diethylamino]-2-Oxoethoxy)-3-Methoxy-Benzeneacetic Acid. Pharmacology 2019, 103, 10-16. [CrossRef]

94. Wikberg, T.; Vuorela, A.; Ottoila, P.; Taskinen, J. Identification of major metabolites of the catechol-O-methyltransferase inhibitor entacapone in rats and humans. Drug Metab. Dispos. 1993, 21, 81-92. [PubMed]

95. Shoghi-Kalkhoran, M.; Faridbod, F.; Norouzi, P.; Ganjali, M.R. Praseodymium molybdate nanoplates/reduced graphene oxide nanocomposite based electrode for simultaneous electrochemical determination of entacapone, levodopa and carbidopa. J. Mater. Sci: Mater. Electron. 2018, 29, 20-31. [CrossRef]

96. Jain, R.; Yadav, R.K.; Dwivedi, A. Square-wave adsorptive stripping voltammetric behaviour of entacapone at HMDE and its determination in the presence of surfactants. Colloids Surf. A 2010, 359, 25-30. [CrossRef]

97. Baghayeri, M.; Tehrani, M.B.; Amiri, A.; Maleki, B.; Farhadi, S. A novel way for detection of antiparkinsonism drug entacapone via electrodeposition of silver nanoparticles/functionalized multi-walled carbon nanotubes as an amperometric sensor. Mater. Sci. Eng. C 2016, 66, 77-83. [CrossRef]

98. Nouri-Nigjeh, E.; Permentier, H.P.; Bischoff, R.; Bruins, A.P. Lidocaine Oxidation by Electrogenerated Reactive Oxygen Species in the Light of Oxidative Drug Metabolism. Anal. Chem. 2010, 82, 7625-7633. [CrossRef] [PubMed]

99. Halbert, M.K.; Baldwin, R.P. Determination of lidocaine and active metabolites in blood serum by liquid chromatography with electrochemical detection. J. Chromatogr. B. Biomed. Appl. 1984, 306, 269-277. [CrossRef]

100. Jurva, U.; Wikström, H.V.; Bruins, A.P. In vitro mimicry of metabolic oxidation reactions by electrochemistry/mass spectrometry. Rapid Commun. Mass Spectrom. 2000, 14, 529-533. [CrossRef]

101. Gul, T.; Bischoff, R.; Permentier, H.P. Optimization of reaction parameters for the electrochemical oxidation of lidocaine with a Design of Experiments approach. Electrochim. Acta 2015, 171, 23-28. [CrossRef]

102. Oliveira, R.T.S.; Salazar-Banda, G.R.; Ferreira, V.S.; Oliveira, S.C.; Avaca, L.A. Electroanalytical Determination of Lidocaine in Pharmaceutical Preparations Using Boron-Doped Diamond Electrodes. Electroanalysis 2007, 19, 1189-1194. [CrossRef]

(C) 2020 by the authors. Licensee MDPI, Basel, Switzerland. This article is an open access article distributed under the terms and conditions of the Creative Commons Attribution (CC BY) license (http://creativecommons.org/licenses/by/4.0/). 